\section{Military Technical College Kobry El-Kobbah, Cairo, Egypt}

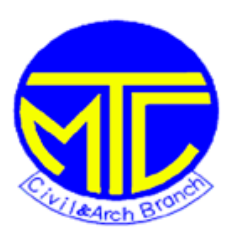

\title{
FACTORS AFFECTING THE UNSYMMETRICAL PUNCHING SHEAR RESISTANCE OF HIGH- STRENGTH CONCRETE SLABS
}

\author{
Osama H. Abdel Wahed ${ }^{1}$, Marwan Shedid ${ }^{2}$, Mansour M.Abdel Halim ${ }^{3}$ \\ ${ }^{1}$ Prof. of RC Structures, ${ }^{2}$ Assist. Prof .of Structural Eng., ${ }^{3} \mathrm{PhD}$ student \\ ملخلص البحث \\ تعتبر البلاطات اللاكمرية من اكثر النظم الانشائية استخداما فى مجال صناعة الانشاءات لما تمتاز بة من مرونة فى استخدامات المنشا

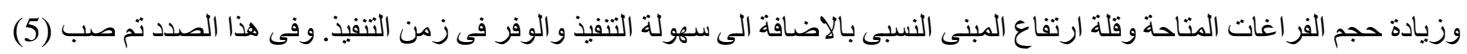 \\ بلاطات بابعاد (1450*1450*150) مم بها عمود خرسانى عند حافة البلاطة وتم تسليح جميع البلاطات بحديد قطر 18مم فى جانب \\ الثد وحديد قطر 10 مم فى جانب الضغط. \\ وقد نم استخدام برنامج للحاسب الآلى يتبع طريقة العناصر المحددة فى تمثيل جميع العينات للتنبؤ بسلوكها. كما تم عمل مقارنة بين النتائج \\ العملية و النظرية لاظهار الاختلاف فى السلوك وتشمل هذه المقارنة احمال الانهيار وكذلك التشكلات و الانفعالات.
}

\author{
$11^{\text {th }}$ International Conference \\ Engineering \\ ICCAE-11-2016
}

\begin{abstract}
One of the most common floor systems is the flat slabs. It provides architectural flexibilities, more clear space, less building height, easier form work and consequently shorter construction time. A serious problem that can arise in flat slab is the brittle punching shear failure due to shear and moment transfer from slabs to columns. As a result of the combined effect of the moment and the shear, stress is no longer uniformly distributed in the vicinity of the column.
\end{abstract}

High- strength concrete is a new type of concrete that having mechanical properties that are far superior to those of conventional concrete. The main characteristics of HSC are then improved.

This thesis discusses the behavior of punching shear strength of flat slabs subjected to centric and eccentric loading, with and without shear reinforcement.

In this way, 5 concrete slabs $(1450 \times 1450 \times 150)$ with edge column were casted to examine different parameters such as concrete strengths and effect of shear reinforcements (central mesh and shear studs).

A finite element program (ANSYS ${ }^{\circledR}$ Release 14) was applied to model the tested specimens to predict the behavior and compatibility between experimental and theoretical investigations to display the difference in behavior considering cracking and failure loads as well as deformations and strains.

Keywords: punching shear, shear reinforcement, flat slabs, and high strength concrete.

\section{INTRODUCTION}

Punching shear is an undesirable mode of failure that occurs without warning and can lead to progressive collapse of large areas of slab or even complete structures .Punching shear can also occur due to large concentrated loads anywhere on the slab area. 


\section{Objectives of present study}

The objectives of this research is to study experimentally and theoretically the behavior of high and- ultra-high strength reinforced concrete slab-column connections subjected to eccentric punching loads.

This study has the following aims:

1) Evaluate the response and ultimate resistance of high and ultra-high performance of reinforced concrete slab panels to punching shear under centric loadings.

2) Explore different possible configurations for shear reinforcements aiming to increase punching shear resistance of the slab-column connections, shear reinforcement configurations to be investigated in this research are shear-studs and central reinforced mesh.

\section{EXPERIMENTAL PROGRAM}

Details of tested specimens

\begin{tabular}{|c|c|c|c|c|c|}
\hline Slab No. & $\begin{array}{c}\text { L*B*t } \\
\mathrm{mm}\end{array}$ & Type & $f_{\mathrm{cu}} \mathrm{N} / \mathrm{mm}^{2}$ & $\begin{array}{c}\text { Type of Shear } \\
\text { Reinforcement }\end{array}$ & Remarks \\
\hline S1 & $1450 * 1450 * 150$ & Edge & 60 & - & EW600 \\
\hline S2 & $1450 * 1450 * 150$ & Edge & 80 & - & EW800 \\
\hline S3 & $1450 * 1450 * 150$ & Edge & 80 & Central Mesh & EM800 \\
\hline S4 & $1450 * 1450 * 150$ & Edge & 80 & Shear Studs & ES800 \\
\hline S5 & $1450 * 1450 * 150$ & Edge & $120+$ Steel Fibers & - & EW1200 \\
\hline
\end{tabular}

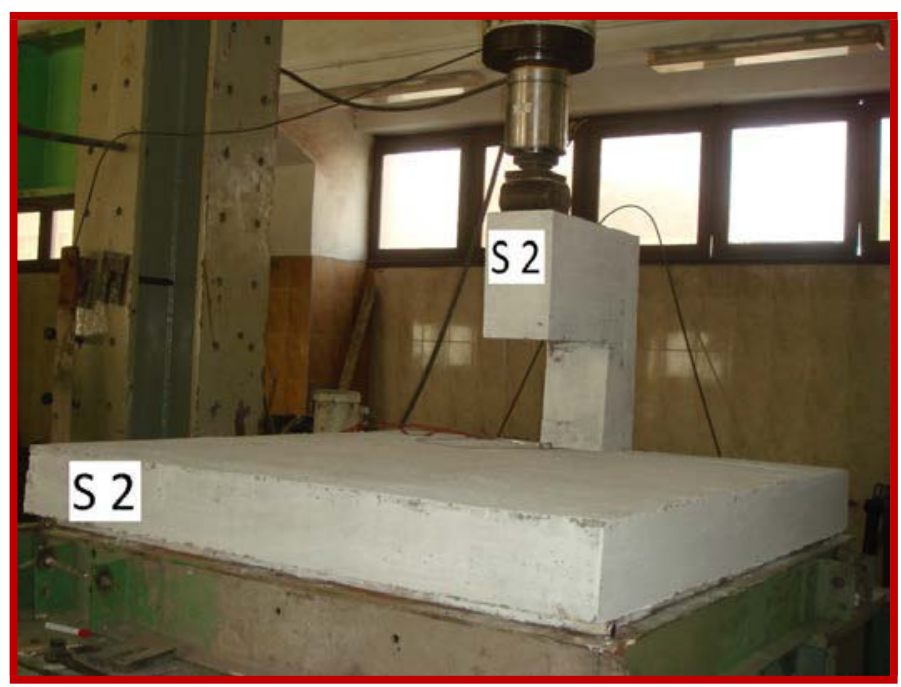

Fig (1) Test set-up for slab S1, S2, S3, S4\&S5 


\section{EXPERIMENTAL RESULTS}

A total of five slab panels with a square column at slab edge were tested under axial vertical loading conditions. The effects of concrete strengths on the behavior of axially loaded concrete are demonstrated. The effect of different types of shear reinforcement of slab panels is compared to that without shear reinforcement and analyzed. Failure modes of all tested specimens are introduced. The following sections provide the experimental results and discussions of these results.

\section{Failure modes}

Figs.(2,3\&4) show two specimens after failure ,all specimens failed in punching mode. Table 4.1 illustrates, failure loads of all tested specimens in this phase .The failure mode of each specimen is described in the following sub-section .

\section{Failure loads and crack patterns of concrete slab -panels}

All specimens failed in a typical punching shear mode. The first crack became visible at about 1/3 the failure load. With increasing load, many radial and circumferential cracks developed on the tension side (bottom) of the slab around the column. Failure happened suddenly with the formation of a typical failure cone around the column. Punching shear failures are diagonal tension failures; and tension correlates best with $\sqrt{f c^{\circ}}$; so slab S5 (EW1200) failed at a load higher than slab S1 (EW600).

\section{Discussion of the experimental results}

The following Sections illustrate the experimental results for examined parameters accompanied by discussion of these results.

\section{Effect of load-deformation behavior}

The load-deflection curves as calculated from the measured data are shown in fig.(5) and fig.(6) for all tested specimens; fig.(5) indicates that; for all tested slabs ,the load- deflection behavior in the ascending branch can be characterized by three load stages, namely first crack load, service load, and ultimate load.

The ultimate punching load ranges from $362 \mathrm{KN}$ for S1to $482 \mathrm{KN}$ for S4. The deflection at maximum load has a band width ranging from $13.2 \mathrm{~mm}$ for S1to $10.5 \mathrm{~mm}$ for S5.

From fig.(5), indicates that deflection of S1(EW600) is greater by 25\% than S5(EW1200), and by 8\% than S2 (EW800), and less by $6 \%$ than S3(EM800) and S4(ES800).

Fig.(6) indicates deflection comparison between slabs S2,S3 and S4, the values of deflection for the three specimens approximately no big difference (4\%).

The above two figures indicated that increasing concrete strength resulting in reducing deflection amount.

\section{Effect of load-concrete strain behavior}

The load-concrete strain curves as calculated from the measured data are shown in fig. (7\&8) for tested specimens.

The load- concrete strain curves show four properties used in the analysis of concrete in compression:

1- The initial slope of the curves increases with an increase in compressive strength.

2- The rising portion of the load-strain curve resembles a parabola with its vertex at the maximum load.

3- The strain at maximum load increases as the concrete strength increases. 
4- The maximum strain reached, decreases with an increase in concrete strength.

Fig (7) shows a comparison between the punching shear load VS. Concrete

Strains of slabs S1,S2 and S5. The figure illustrates that punching shear loads Increase with increasing of concrete strengths; S5 increased by 18\% than S1 and S3 increased by 25\% than S1. The strains of S1 and S2 are approximately the same .

\section{Effect of load- concrete and shear reinforcement behavior}

The load- concrete shear reinforcement strain curves as calculated from the measured data are shown in fig. (8) for tested specimens. The figure shows a comparison between punching shear load VS. concrete and shear reinforcement strains of slabs S2, S3 and S4. The figure illustrates that punching shear resistance increases with using shear reinforcement; slab S3 increased by 21\% higher than S2; and S4 increased by $29 \%$.

Table (1) Failure and cracking loads for test specimens

\begin{tabular}{|c|c|c|}
\hline Slab & $\begin{array}{l}\text { Failure load } \\
\qquad(\mathbf{k N})\end{array}$ & $\begin{array}{c}\text { Load V } \\
(\mathbf{k N}) \\
\text { AT First crack }\end{array}$ \\
\hline S1 & 362 & 100 \\
\hline $\mathrm{S} 2$ & 375 & 180 \\
\hline S3 & 453 & 220 \\
\hline S4 & 482 & 220 \\
\hline S5 & 426 & 240 \\
\hline
\end{tabular}




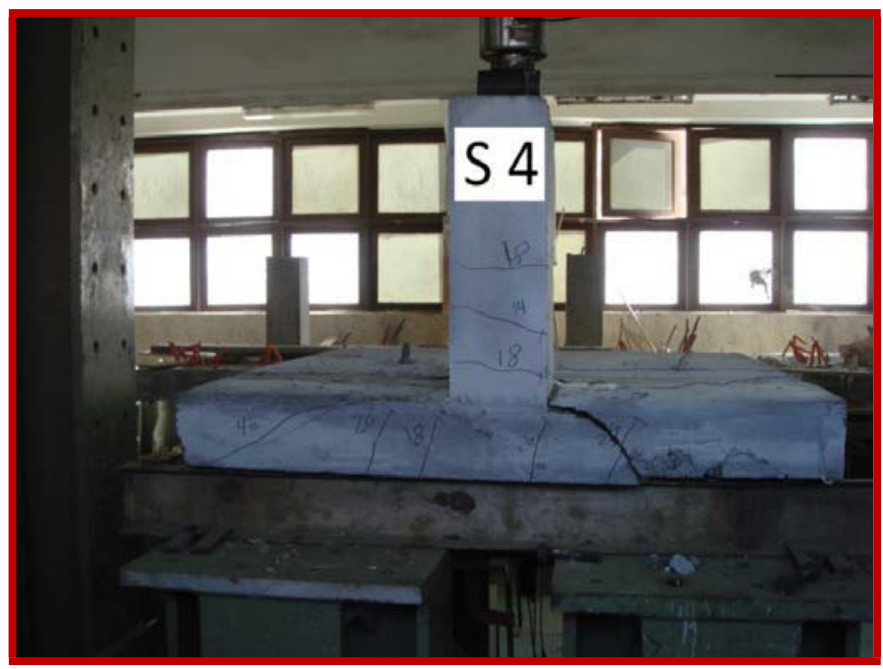

Fig (2) Cracks pattern at tension side of slab S1

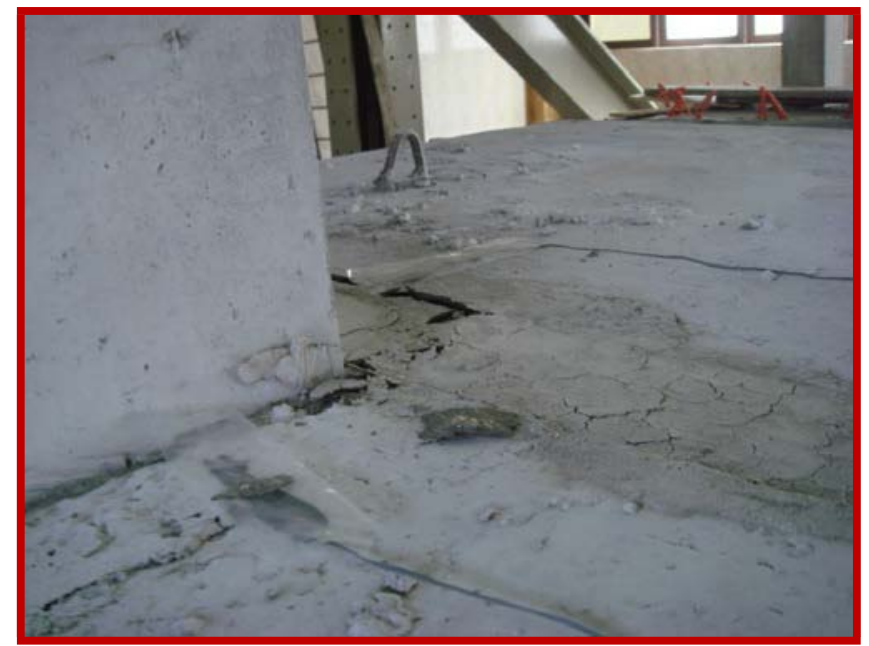

Fig (3) Punching shear failure at column at top surface of slab S3

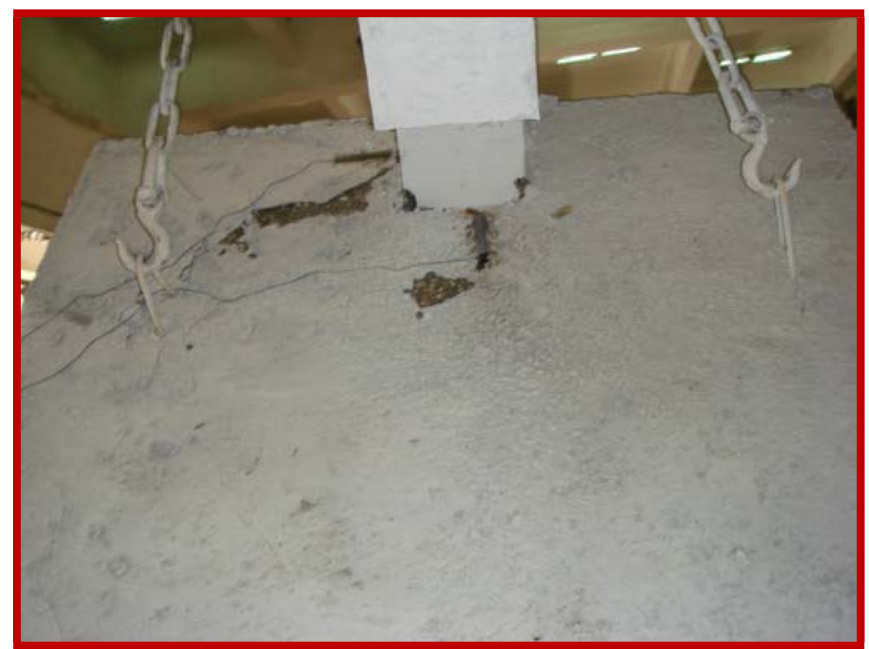

Fig (4) Punching shear failure (penetration) at column at top surface of slab S5 


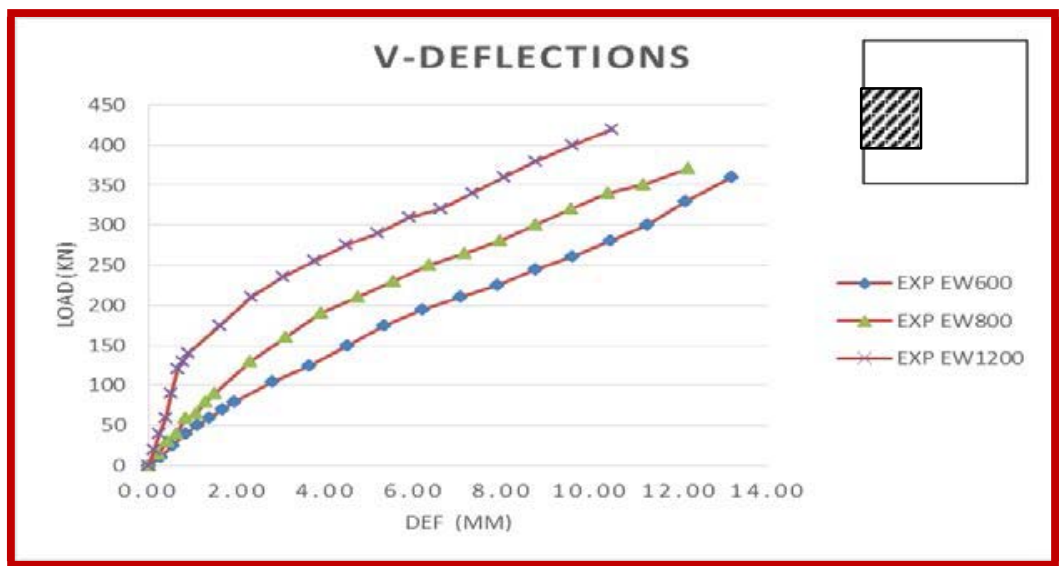

Fig (5) Load deflection curves at column location for slabs S1, S2\&S5

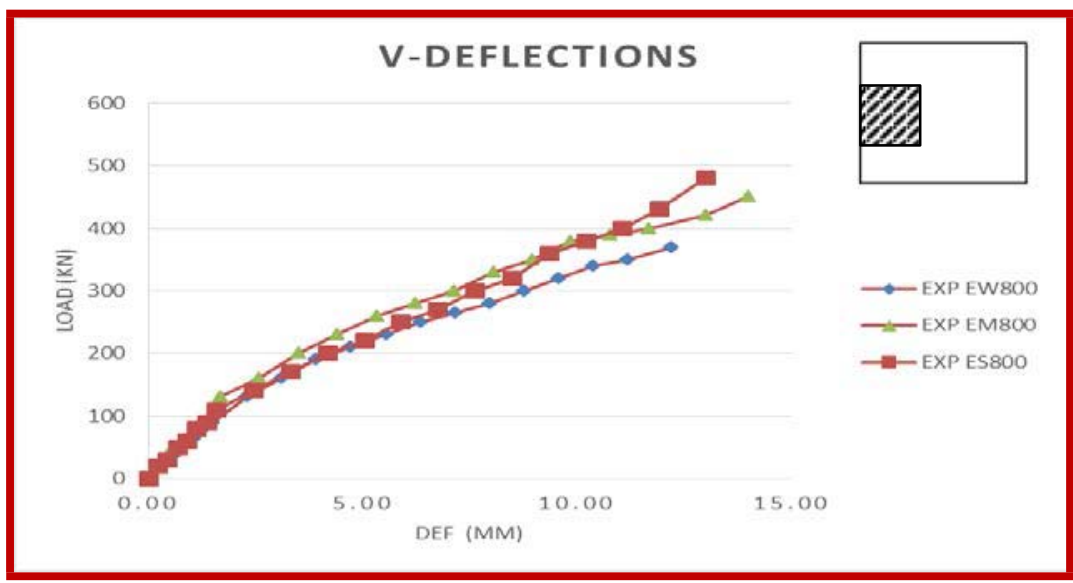

Fig (6) Load deflection curves at column location for slabs S2,S3\&S4

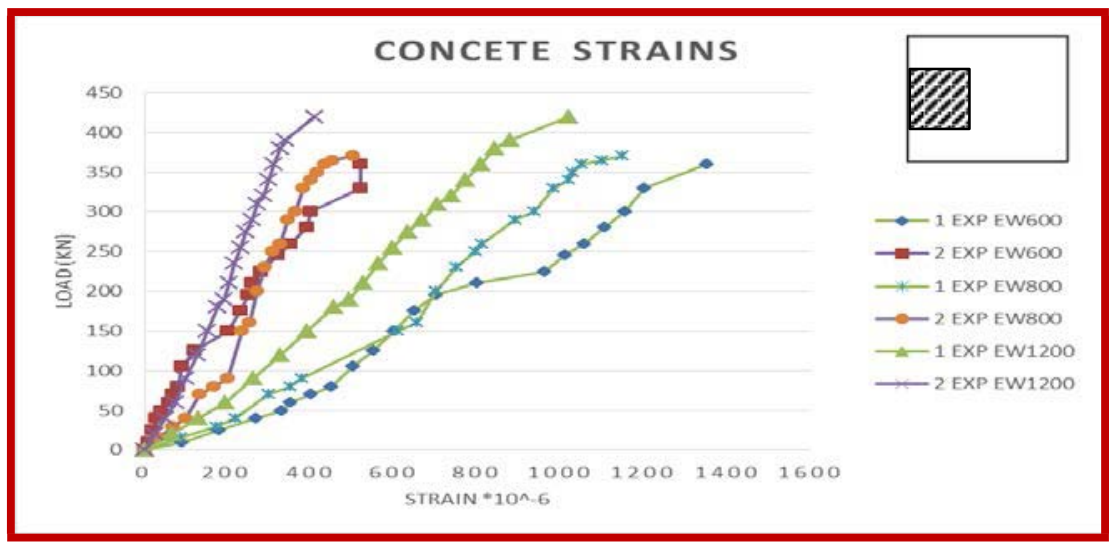

Fig (7) Comparison between concrete strains for slabs S1, S2\&S5 


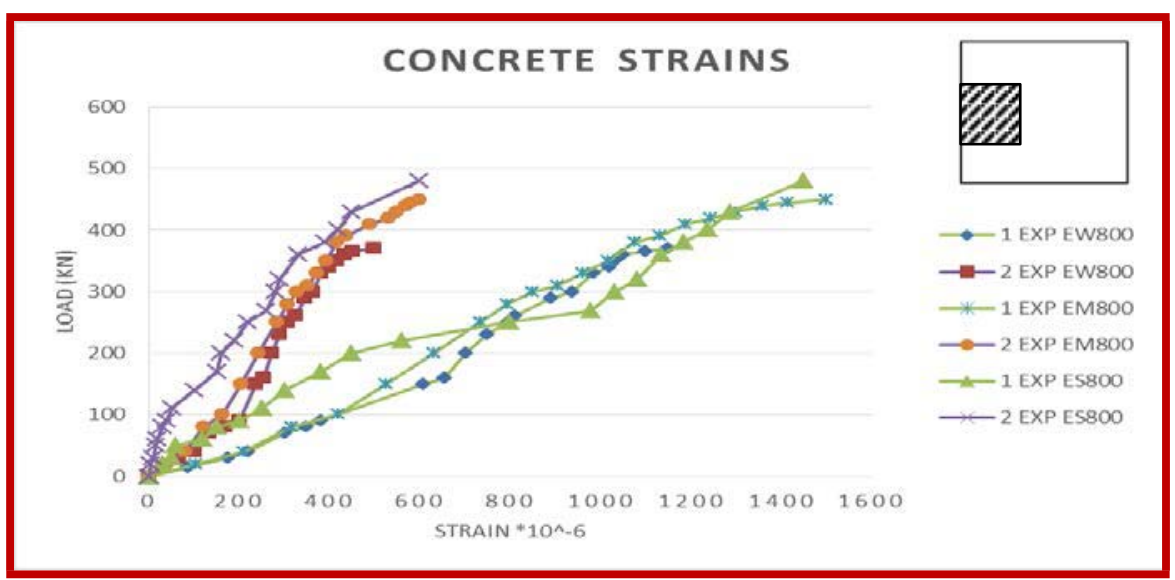

Fig (8) Comparison between concrete strains for slabs S2, S3\&S4

\section{FINITE ELEMENT ANALYSIS}

Finite element method (FEM) is a process which finite degrees of freedom can be approximated to be an assemblage of element each with a specified number of unknowns. In recent years, the use of finite element analysis has increased due to progressing knowledge and capabilities of computer software and hardware. It has now become the choice method to analyze concrete structural components. The use of computer software to model these elements is much faster, and extremely cost-effective.

Finite element model was developed to simulate five specimens, S1 through S5, from linear through nonlinear response and up to failure, using the software package ANSYS ${ }^{\circledR} 14$. Comparisons were done with respect to load-deflection relationship below loaded point of the slab, failure loads, and cracks patterns at failure. Modeling simplifications and assumptions developed during this research are presented below.

\section{ELEMENT TYPES}

Concrete Element (Solid 65)

Reinforcement Element (Link 180)

Shear reinforcement element (Beam 188)

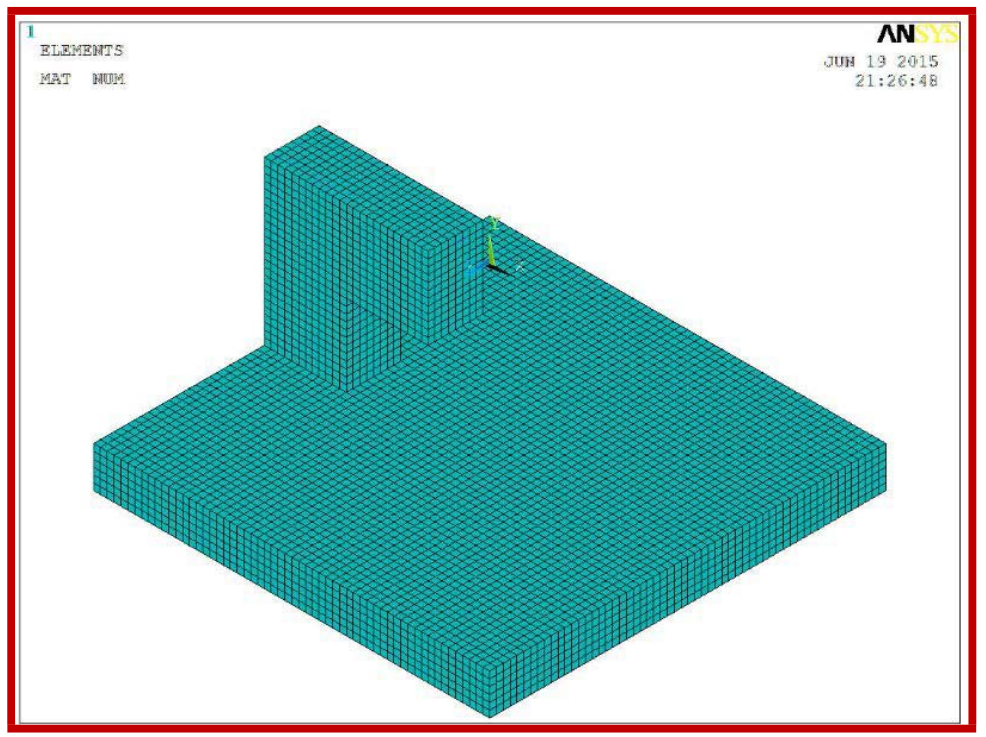

Fig. (9) finite element mesh used for concrete edge column- slab 


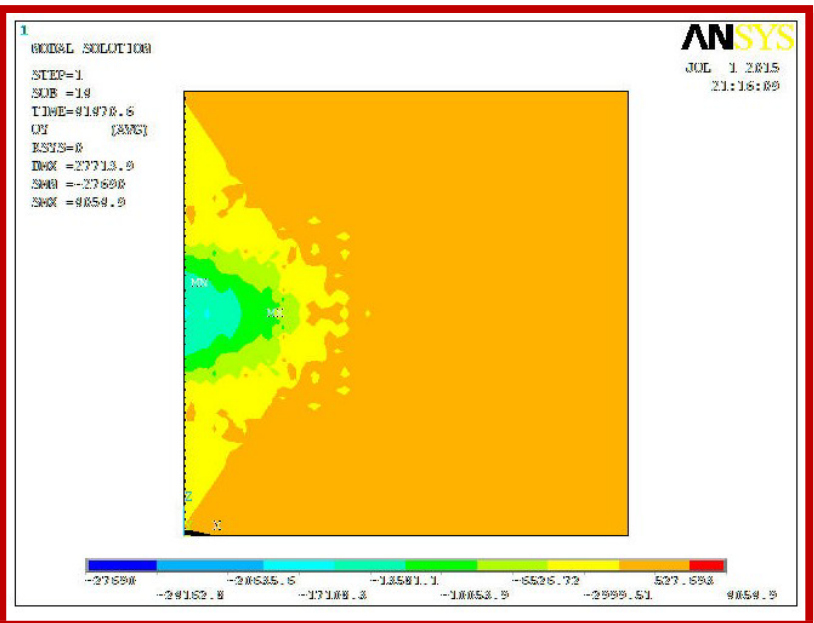

Fig. (10) Typical contour lines of strain distribution of slab S3

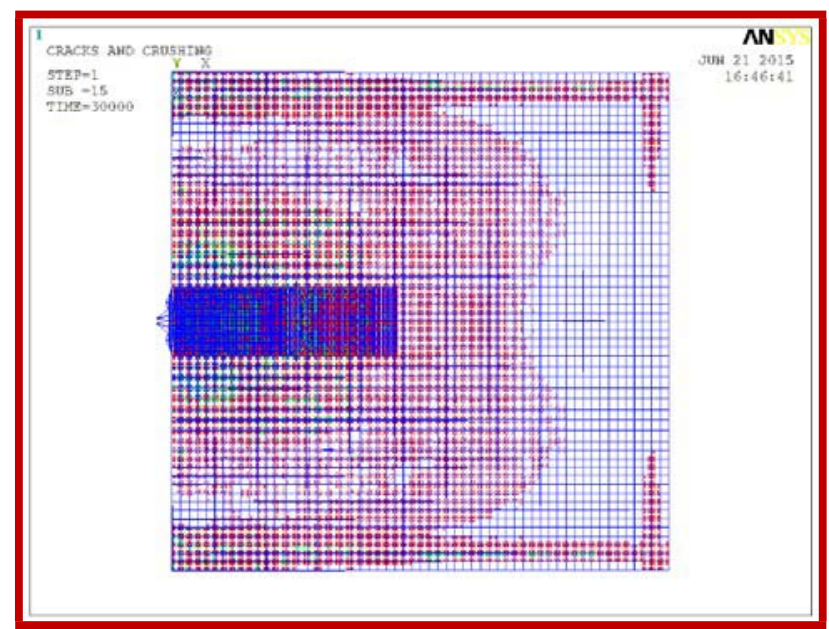

Fig. (11) Typical crack pattern at failure of edge column slab

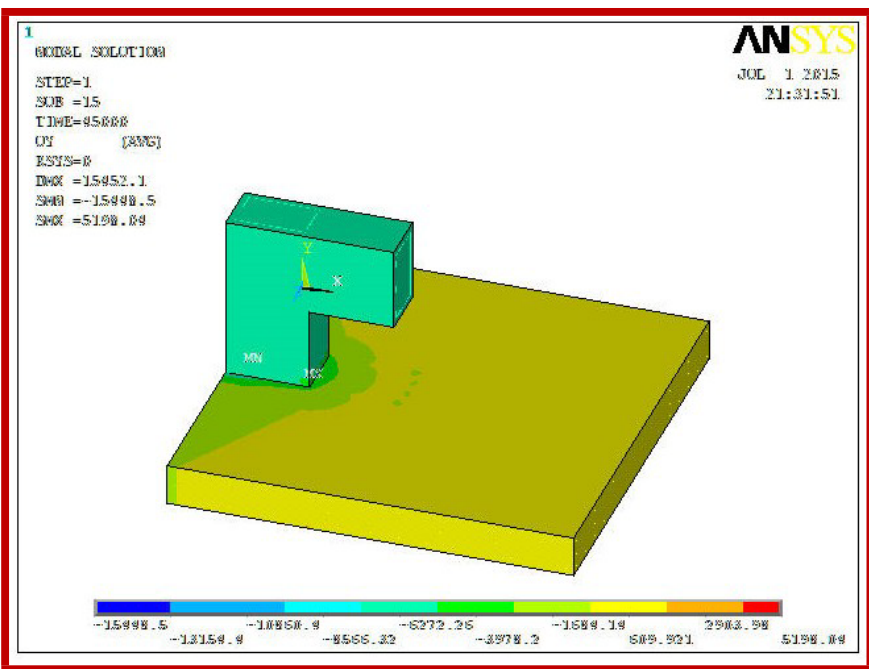

Fig. (12) Typical contour lines of strain distribution of slab S5 


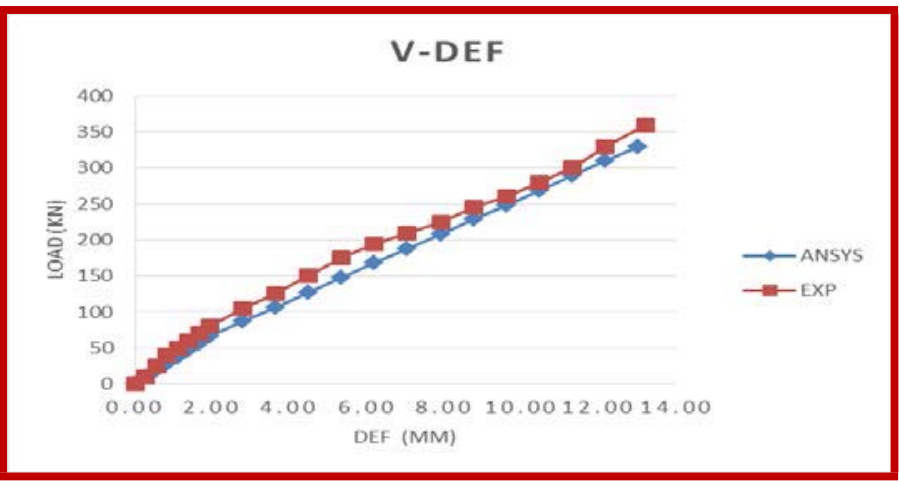

Fig. (13) Experimental VS. FE results of deflection for S1 (EW600)

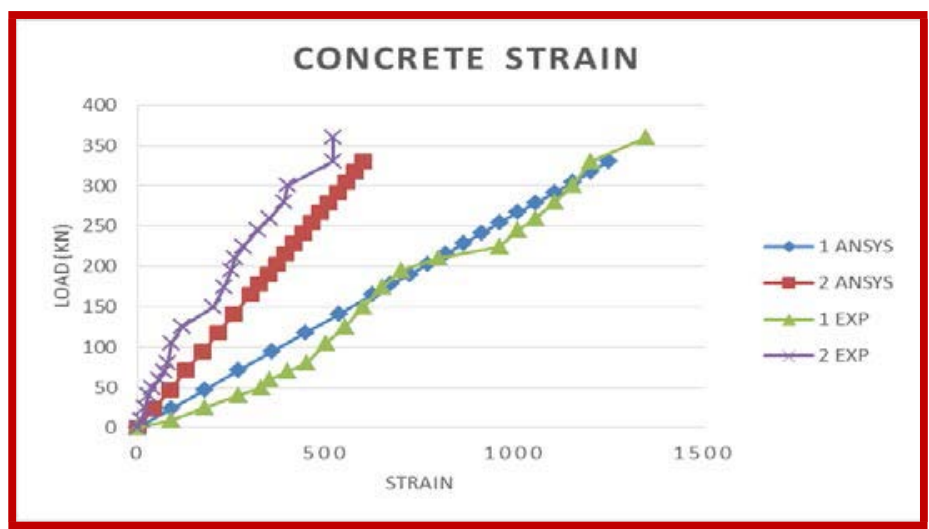

Fig. (14) Experimental VS. FE results of concrete strains for S1 (EW600)

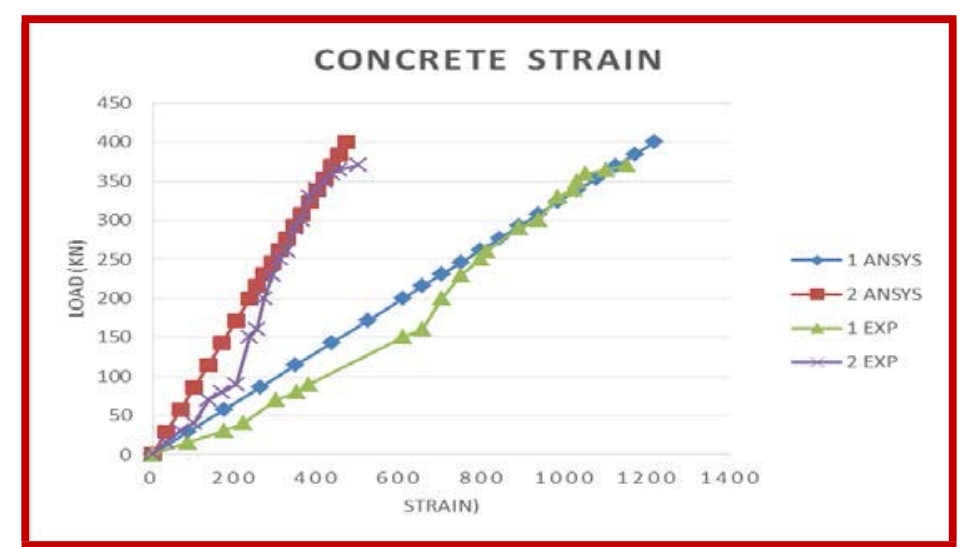

Fig. (15) Experimental VS. FE results of concrete strains for S2 (EW800) 


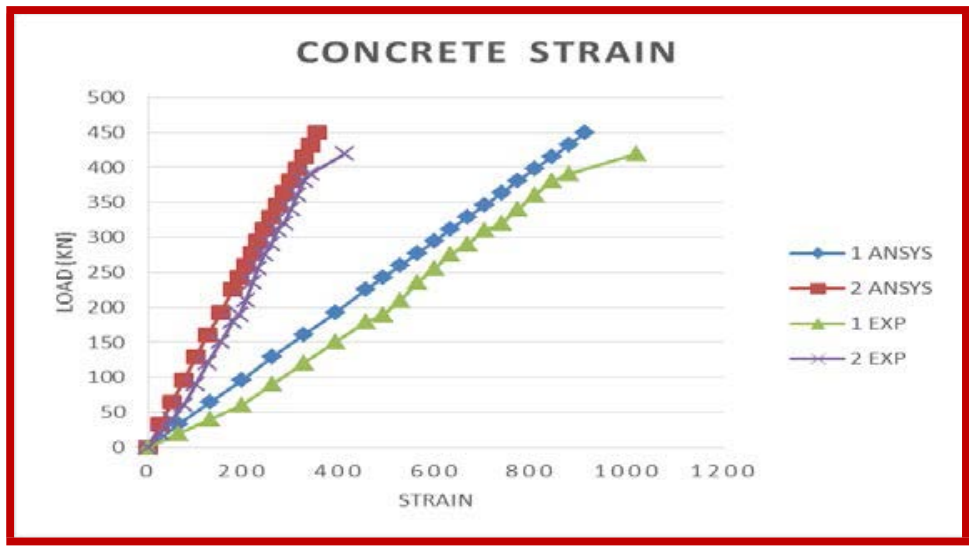

Fig. (16) Experimental VS. FE results of concrete strains for S5 (EW1200)

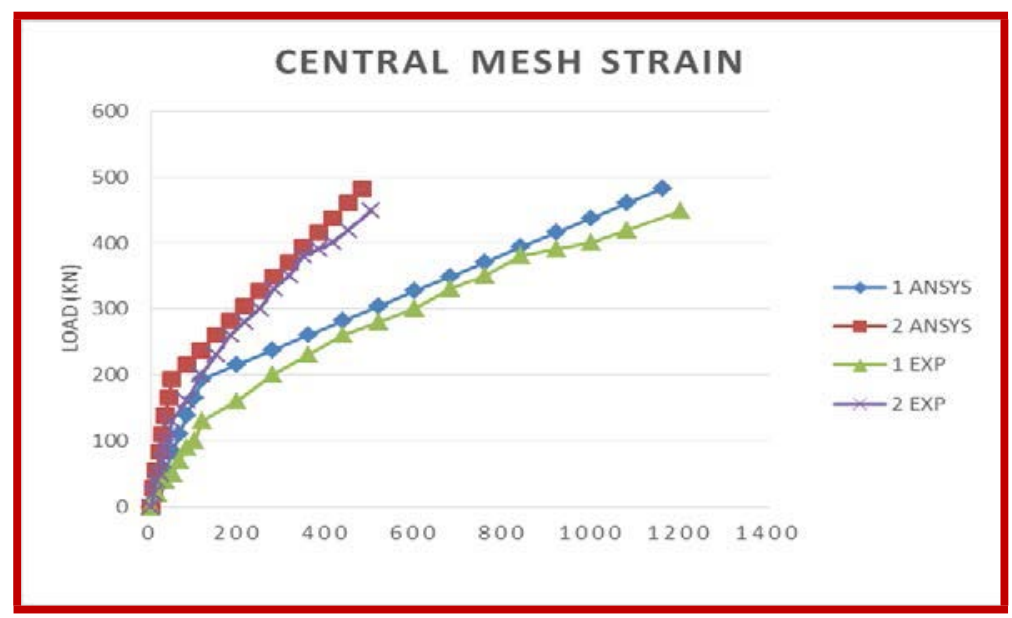

Fig.(17) Experimental VS. FE results of central mesh strains for S3 (EM800)

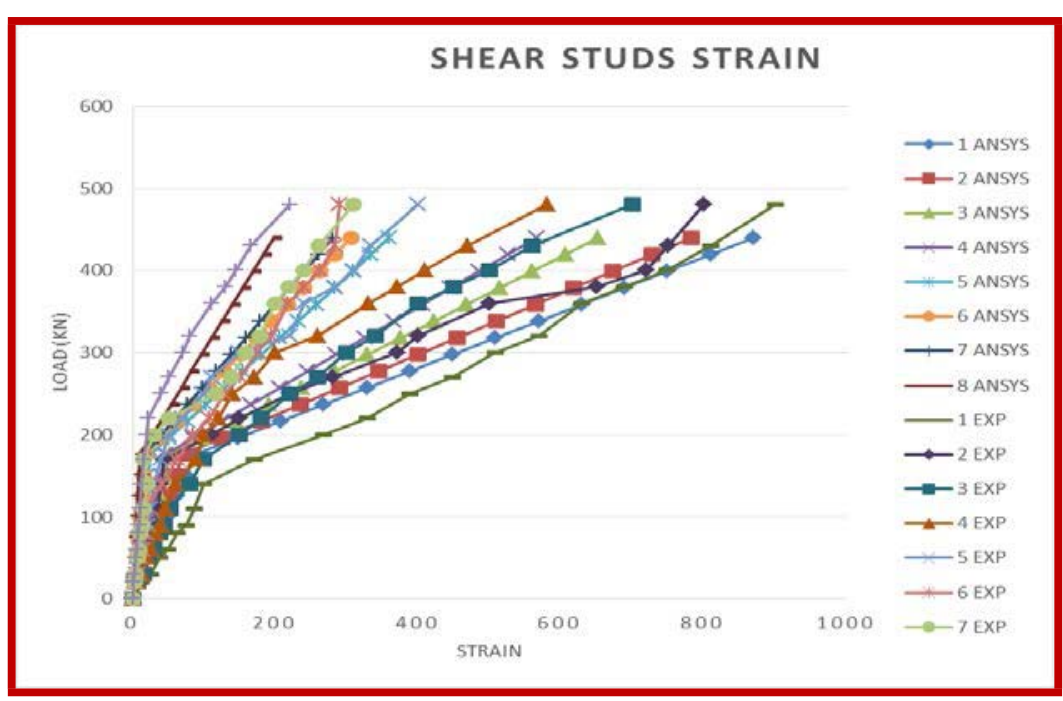

Fig.(18) Experimental VS. FE results of central mesh strains for S4 (ES800) 


\section{CONCLUSIONS}

Based on the results obtained from experimental and analytical investigation, the following main conclusions were furnished:

1 - The shear stress at punching shear failure increasing with increase of compressive strength of concrete.

2 - Concrete with higher strength provided, has less deflection and less strain at failure Because of its higher modules of elasticity.

3 - The tensile capacity inherent to high strength concrete can significantly improve the Punching shear capacity for a slab.

4- The ultimate load-deformation behavior of slabs subjected to punching load shows harmonic behavior of three stages; first, drop of load-deflection curve after reaching maximum load, second, resistance of tension reinforcement, and third, pure tension reinforcement resistance.

5- The final shape of the punching cone is completed after the tension reinforcement starts to yield and the column stub starts to penetrate through the slab.

6- Slabs with shear reinforcement especially in case of using central mesh and shear studs give higher punching shear resistance with a ratio $20 \%$ and $15 \%$ respectively than slabs without shear reinforcement.

7 - Shear reinforcement can change mode of failure from punching to flexure and at the same time ensure that if punching failure progresses through the shear reinforced zone it will be ductile allowing for large slab-column deformations .

8 - The choice of a type of shear reinforcement should be based on reinforcement performance, simplicity, ease of installation and availability.

9- From the comparison of the experimental works ; and FEM results, we find that :

\section{- DEFLECTIONS:}

- All figures show that the predicted values of vertical deformation were less than the measured values in the experimental work at the same failure load level. This is attributed to the large bending stiffness of analytical specimens, resulting from the full bond assumed in the FE modeling

\section{- CONCRETE STRAINS:}

- It is shown that the values of the predicted and measured strains had good agreement together in the uncracked stage, represented by the first slope of the load-strain curve . After cracking of concrete, the predicted values of strains were different from the measured ones by range of 2 to $16 \%$. This is attributed to the effect of tension stiffening, which enhanced the stiffness of the slabs experimentally. On the other hand, the full bond, assumed in the FE modeling, played an imported role in improving the stiffness of the slabs analytically.

- SHEAR REINFORCEMENT STRAINS:

- It is shown that the values of the predicted strains are less than the measured values, at the same load levels with a range from 1 to $11 \%$. This indicates that the analytical models of the five specimens are stiffer than the actual specimens. This attributed to the assumed full bond.

10 - It is recommended that the Egyptian code of practice should consider the effect of shear reinforcement for flat slab structures as a design tool. 


\section{REFERENCES}

1- $\quad$ ACI 318 - 11. Building Code Requirement for Reinforced Concrete, American Concrete Institute, Farmington Hills, Mich.

2- $\quad$ CSA A23.3 (2004), Design of Concrete Structure, Canadian Standards Association.

3- $\quad$ BS 8110 (1997): Structural use of Concrete, Part 1: Code of practice for design construction, British Standards, London.

4- $\quad$ EC 2-1-1 (2004): Euro Code 2: design of Concrete Structures - Part 1: General rules and rules for buildings.

5- $\quad$ Fee Kiong LIM and B. Vijaya Rangan. (1955) Studies on Concrete Slabs with Sstud Reinforcement in the Vicinity of Edge and Corner Columns. ACI Structural Journal V.92, No.5,Nov.

6- Neil Hammil and Amin Ghali "Punching Shear Resistance of Corner Slab-Column Connection," ACI Structural Journal, V.91, No.6.

7- $\quad$ Tetsuya Yamada , Antonio Nanni, and Katsushiko Endo . 1992 "Punching Shear Resistance of Slabs: Influence of Reinforcement Type and Ratio," ACI Structural Journal, V. 89, No.5.

8- Mitchell,D.,Cook,W.D.,Dilger,W.,"Effects of Size, Geometry and Material Properties on Punching Shear Resistance" (2005), Punching Shear in Reinforced Concrete Slabs, Editor Maria Anna Polak,American Concrete Institute, SP-232.

9- W.Dilger, G. Birkle, and D.Mitchell "Effect of Flexural Reinforcement on Punching Shear Resistance "(2005), Punching Shear in Reinforced Concrete Slabs, Editor Maria Anna Polak,American Concrete Institute, SP-232.

10- Polak, M.A., (2005), Punching shear in reinforced concrete slabs" ACI, Farmington Hills, Michigan.

11- W.Dilger, G. Birkle, and D.Mitchell "Effect of Flexural Reinforcement on Punching Shear Resistance "(2005), Punching Shear in Reinforced Concrete Slabs, Editor Maria Anna Polak,American Concrete Institute, SP-232.

12- ACI Committee 421 (1999). "Shear reinforcement for slabs". ACI 421.1 R- 99, Technical repot, American concrete Institute, Detroit, Michigan.

13- Nilson, A., H., Darwin, D., and Dolan, C., W., 2004, "Design of concrete structures" Thirteen Edition, New York, Mc Graw-Hill. 